\title{
Efficiency of the European Social Fund Contribution to the Regions of Latvia
}

\author{
Ilze Latviete* \\ Department of Economics, LLU
}

\begin{abstract}
From 2004 till mid-2007, the economics of Latvia experienced fast development, which to some extent was influenced by accessing the European Union (EU), which in its turn provided access to the EU funds and subsequently to significant investment in the country's development, thus also affecting the topicalities of social security and employment. Because of the world recession, the EU has experienced an economic downfall which hit Latvia and its regions very hard, causing a significant reduction in the economic activity, increase in the unemployment level, and the risk of social stratification. To facilitate the socio-economic development of the regions, to increase the level of welfare in the regions with lower socio-economic development indicators, as well as to prevent the possibility of appearance of unfavourable situations in the future, it is necessary to use correctly the EU funds available in Latvia, including the financing of the European Social Fund (ESF). In the period from 2004 till 2010, the Riga region has acquired 33\% of the total ESF financing in the welfare sector, Latgale has the second largest financing $-25 \%$, but the other resources have been acquired in a more or less equal amounts in the other regions: Kurzeme (16\%), Zemgale (14\%), and Vidzeme (12\%). The ESF financing in the welfare sector has influenced the socio-economic indicators of the regions. Functional correlations are observed among the ESF financing in the welfare sector and the value changes in the number of registered unemployed persons, job seekers and the territory development index.
\end{abstract}

Key words: European Social Fund, financing, activity, development of territories.

\section{Introduction}

There are no territories in Latvia that would not have development opportunities, but there are socialeconomic differences of the regions - in nature and cultural environment, in traditions, economic activity, and income. Regions of Latvia do not exhibit balanced development, and with every year the differences even grow. It is determined by several significant factors (e.g. the unfavourable economic situation in the country) that affect territories and households with a lower level of economic development, negative natural population growth rate and part of the labour force of the native population leaving the country, enhancement of emigration facilitating factors, and some others. The side effects created by the regional differences are: state economic development opportunities are worsening and the efficiency of resource use is decreasing, the stratification of society is enhanced, the demographic and social load is increasing fast, the unemployment is increasing, as well as other negative phenomena in territories with a lower development level. Along with the increase of the unemployment and poverty level, the level of crime, drug addiction and alcoholism also increases and, as a result, general social degradation sets in, which can spread in the entire country and cause a deep economic crisis.

The EU funds are the main financial instrument that supports less favourable areas and unsecured groups of population to reduce socio-economic differences between the Member States and their regions. Thus, Latvia receives financing as a country not particular its regions, as it is practised in most of the EU Member States.

Previous research shows that regional opportunities and interests to acquire the EU funds financing are not equal. The response of the region's economics on the efficiency of the invested resources is not identical either because there are different economic advantages and economic development interests between the regions (Saktina, 2008). In the territories which have attracted larger EU funds financing faster development has taken place, whereas the improvement of the socio-economic indicators in the other regions is slower, their differences continue increasing.

\footnotetext{
* Author's email:

Ilze.Latviete@1m.gov.lv
} 
Statistical data of different institutions shows that resources of the EU funds have satisfied the needs of the capital Riga and the territories included in its surroundings. However, Keišs and a group of authors (Keišs et al., 2008) question the view that the largest emphasis in the EU funds distribution is placed on the fact that Riga, its surroundings and the large development centres will ensure high growth rates of the gross domestic product (GDP) also in the future, which will enhance the consistent increase of the welfare level of the population of entire Latvia up to the level of average prosperous inhabitants of the EU member states. The group of researchers continue to test this hypothesis also in 2008 performing monitoring observations and carrying out research about the unused opportunities in the regional development of the country.

In the research of the Latvian State Institute of Agrarian Economics and the World Bank, Riga region and Zemgale were marked as the largest beneficiaries of the funding from the EU and state support programmes for agriculture and rural development (Saktina, \& Meyers, 2005). Slightly later, it was also concluded by "PKC" Ltd (PKC SIA, 2005), indicating that the distribution of the EU funds between the various territorial parts of the country and the regions is not even. A significantly smaller amount of funding reaches those territories of the country where the indicators of the economic activity, employment and welfare level are the worst (e.g. in Latgale region), or territories that are further from the capital or the main transport highways.

Professor Bikse (2009) in her work notes that resources of the EU funds are used inefficiently in Latvia and the use of the EU funds resources lacks clear vision what the significant national problems to which the EU funds resources should be allocated are. Often resources are not allocated for solving issues important for Latvia but are fragmented between different ministries for funding implementation of similar or very close activities. There is no businesslike cooperation between ministries to commonly allocate resources for solving problems important for Latvia. The funding is distributed between different state institutions to implement similar measures, but the problem solution between the ministry levels is missing.

The need for attracting the EU funds as well as the effectiveness of the acquisition of the available financing in Latvia has been researched by Dubra (2006, 2009), Slavinska (2005), Zvirgzdina (2007), Pilvere (2007), Tetere and Pilvere (2007),
Tetere (2009), Vaidere (2006), Blumberga (2010), Haite (2010), Vītola and Šenfelde (2010), and other researchers. The issues regarding attracting and introducing the EU funds have been studied also in other EU member states, for example, in Poland - by Mickievicz (2007), Sienkiewicz (2009), Zawojska (2009), Marciniak (2009), Mickievicz and Mickievicz (2010), and other researchers, in Lithuania - by Meyers, Kazlauskiene, Naujokiene, and Kriščiukaitiene (2006), Ribašauskiene, Kairyte, and Meyers (2007), in Hungary - by Mizik (2007), and in Ireland - by Clinch, Convery, and Walsh (2002), and Sweeney (2008).

When evaluating the significance of funds in stimulating economics, the common opinion of researchers is positive. However, the analysis of the research and data about the acquisition of the EU funds does not reveal a distinct correlation between the welfare and development indicators of particular territories and the respective allocation of funds. In the acquisition of the EU funds the situation that a less developed territory receives the largest financing is not formed, but it cannot be claimed either that the most developed region would absorb the proportionally largest funding.

To facilitate the social and economic development and growth of Latvia and its regions, the previous experience in the use of the EU funds has to be taken into consideration. The EU funds introduction period in Latvia has been short, not eight years yet. During this period, about six years have been allocated for research at the national level, in which research has been performed in total, about all the EU funds available in Latvia, not dividing them by separate areas and some specific research information by regions. Research that would focus exactly on the investment in the ESF financed measures administered by the Ministry of Welfare for the support of employment and social inclusion (hereinafter referred to as welfare sector) as the main research object has not been performed. Evaluation of the theoretical and socio-economic aspects of the ESF is topical to develop recommendations for the elaboration of the efficient use (allocation and acquisition) of the EU funds, including ESF.

Therefore the research goal has been defined: to evaluate the effectiveness of the ESF investment in Latvia and its regions in the welfare sector.

To attain the goal, the objectives that were set are: 1) to evaluate the efficiency of the ESF investment in the welfare sector in Latvia and its regions, and 


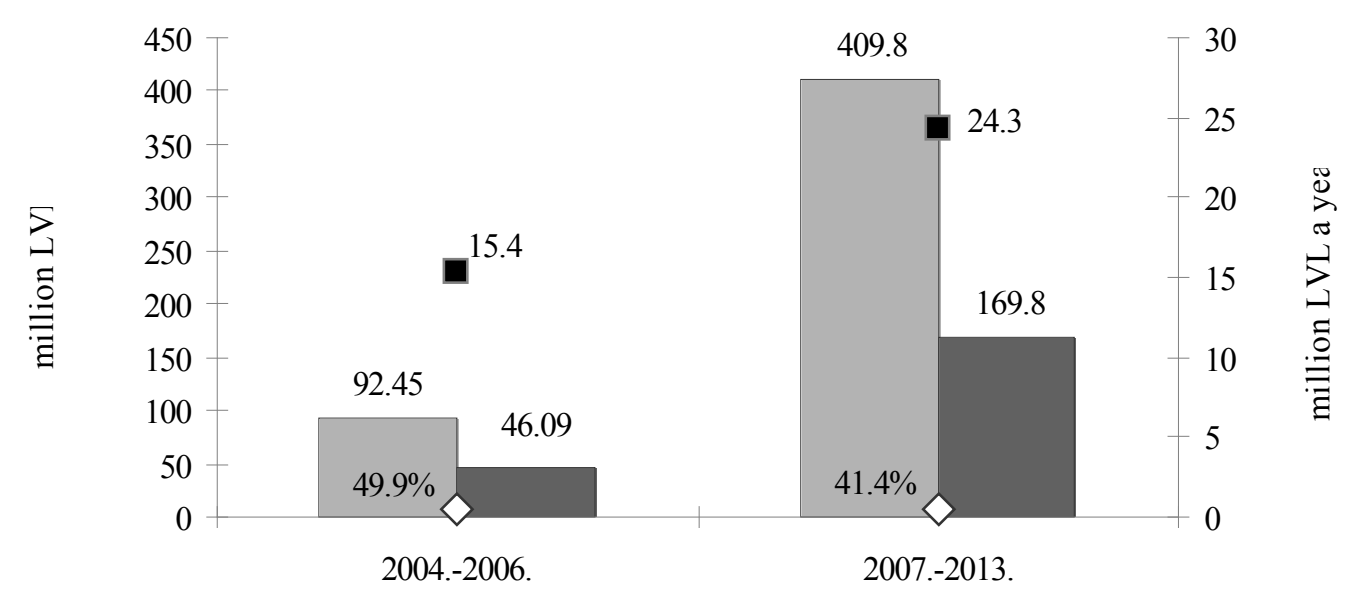

Total ESF financing

Annual average

ESF financing in the welfare sector $\diamond$ The proportion, $\%$

Source: data of the Ministry of Financing (Finanšu ..., 2011a, b) and the Ministry of Welfare (Labklājības ..., 2011) on July 31, 2011.

Fig. 1. ESF financing in Latvia and in the welfare sector in the 2004-2006 and 2007-2013 planning periods, million LVL.

2) to evaluate the impact of the ESF investment in the welfare sector on the socio-economic indicators of the regions of Latvia.

\section{Materials and Methods}

The normative documents regulating the use of the EU funds, laws of the Republic of Latvia, regulations of the Cabinet of Ministers, strategic and planning documents, research of Latvian and foreign scientists, information published by the Central Statistical Bureau (CSB) and State Employment Agency (SEA), information of the ministries of the Republic of Latvia and institutions involved in the ESF administration, and outcome data on the ESF introduction in the EU as well as at national and regional level were used to study the theme.

The main research methods applied: monographic descriptive method, method of checking correspondence between documents of different levels, analysis and synthesis methods to research problem elements and to synthesize interconnections, or to define regularities, obtaining and storing facts, statistics and other data, as well as specific information about the measures implemented by the EU Structural Funds.

\section{Efficiency of ESF financing in the welfare sector in Latvia and its regions}

In Latvia, in the planning periods 2004-2006 and 2007-2013, in total the ESF financing in the amount of LVL 502.25 is available, of which LVL 215.89 mill. or $43 \%$ is in the welfare sector (see Fig. 1).

Evaluating the information summarised in Figure 1, a conclusion can be made that in the planning period 2004-2006 the available and acquired ESF financing in the welfare sector was $49.9 \%$ of the total EFS financing available and acquired in Latvia. Respectively, in the planning period 2007-2013, 41.4\% of the total ESF financing available in Latvia is available to the welfare sector, which is 3.7 times larger available financing than in the planning period 2004-2006. Taking into consideration the length of the planning period in years (3 and 7 years respectively), it can be observed that in the planning period 2004-2006 the average financing per year was LVL 15.4 mill., but in the planning period 2007-2013 it was already LVL 24.3 mill., which is 1.6 times larger. This is a significant increase in financing, which, according to the goal determined by the State Strategic Framework Document for 20072013 (Finanšu .., 2007), is support to the enhancement of a faster state and economic growth, including reducing the differences in unfavourable development indicators in different parts of the country's territory.

From 2004 till 2010, LVL 240.85 mill. of ESF financing have been invested in total in Latvia and its regions, out of which LVL 113.34 mill. or $47.07 \%$ were in the welfare sector. To analyse the efficiency 
Acquired ESF financing in the welfare industry in Latvia and its regions from 1 January 2004 till 31 December 2010, LVL, \%

\begin{tabular}{|c|c|c|c|c|c|c|}
\hline ESF financing, LVL & Riga & Kurzeme & Vidzeme & Latgale & Zemgale & Latvia \\
\hline Total in the welfare sector, mill. LVL & 37.7 & 17.8 & 14.0 & 28.4 & 15.5 & 113.4 \\
\hline Proportion in the welfare sector, $\%$ & 33 & 16 & 12 & 25 & 14 & - \\
\hline Per capita, LVL & 34 & 57 & 57 & 79 & 54 & 49 \\
\hline $\begin{array}{l}\text { Per } 1 \text { economically active } \\
\text { inhabitant, LVL }\end{array}$ & 66 & 122 & 127 & 170 & 114 & 100 \\
\hline Per 1 unemployed, LVL & 1065 & 1320 & 1357 & 1113 & 1227 & 1165 \\
\hline $\begin{array}{l}\text { Per } 1 \text { economically active } \\
\text { businessperson, LVL }\end{array}$ & 861 & 3053 & 3303 & 6089 & 3454 & 1799 \\
\hline In the employment area, mill. LVL & 27.4 & 13.4 & 11.2 & 21.6 & 12.4 & 86 \\
\hline Proportion in the employment area, $\%$ & 32 & 16 & 13 & 25 & 14 & - \\
\hline Per capita, LVL & 25 & 43 & 46 & 60 & 43 & 37 \\
\hline $\begin{array}{l}\text { Per } 1 \text { economically active } \\
\text { inhabitant, LVL }\end{array}$ & 48 & 92 & 101 & 130 & 91 & 76 \\
\hline Per 1 unemployed, LVL & 774 & 992 & 1080 & 849 & 983 & 883 \\
\hline $\begin{array}{l}\text { Per } 1 \text { economically active } \\
\text { businessperson, LVL }\end{array}$ & 626 & 2296 & 2629 & 4643 & 2767 & 1365 \\
\hline In the social inclusion area, mill. LVL & 10.3 & 4.4 & 2.9 & 6.7 & 3.1 & 27.4 \\
\hline Proportion in the social inclusion area, $\%$ & 38 & 16 & 10 & 25 & 11 & - \\
\hline Per capita, LVL & 9 & 14 & 12 & 19 & 11 & 12 \\
\hline $\begin{array}{l}\text { Per } 1 \text { economically active } \\
\text { inhabitant, LVL }\end{array}$ & 18 & 30 & 26 & 40 & 23 & 24 \\
\hline Per 1 unemployed, LVL & 291 & 327 & 277 & 264 & 244 & 281 \\
\hline $\begin{array}{l}\text { Per } 1 \text { economically active } \\
\text { businessperson, LVL }\end{array}$ & 235 & 757 & 674 & 1446 & 688 & 435 \\
\hline
\end{tabular}

Source: data of the Ministry of Financing (Finanšu ..., 2011a), the Ministry of Welfare (Labklājības ..., 2011), and Central Statistical Bureau of Latvia (CSB, 2011a, b).

of the acquired ESF financing in the welfare sector in Latvia and its regions until December 31, 2010, the author has summarised the information about the contribution of ESF financing in the welfare sector in the planning periods 2004-2006 and 2007-2013 (see Table 1).

Based on the information summarised in Table 1 about the distribution of the acquired ESF financing in the welfare sector in the regions in the period from 2004 till 2010, several conclusions can be made:

- the total acquired ESF financing in the welfare sector has been LVL 113.4 mill., of which the largest part (33\%) was attracted in Riga region. The second largest amount of the ESF financing has been in Latgale, where $25 \%$ of the total acquired ESF financing in the welfare sector was attracted to the regional development. In the other three regions, the proportion of the acquired ESF financing differs by two to four percent points, which indicates to an equal distribution of financing among these three regions;

- in the distribution of the attracted ESF financing per capita, the highest indicator has been in Latgale, which was 2.3 times higher than in Riga region and exceeded the average indicator of the country 1.6 times. In the other three regions, the distribution of the attracted ESF financing per capita, like in the distribution of the ESF financing in the welfare sector per capita, indicates to equal distribution of financing. In Kurzeme and Vidzeme, the indicators have been the same - LVL 57, but in Zemgale only a three lats lower ESF financing per capita has been attracted (LVL 54); 


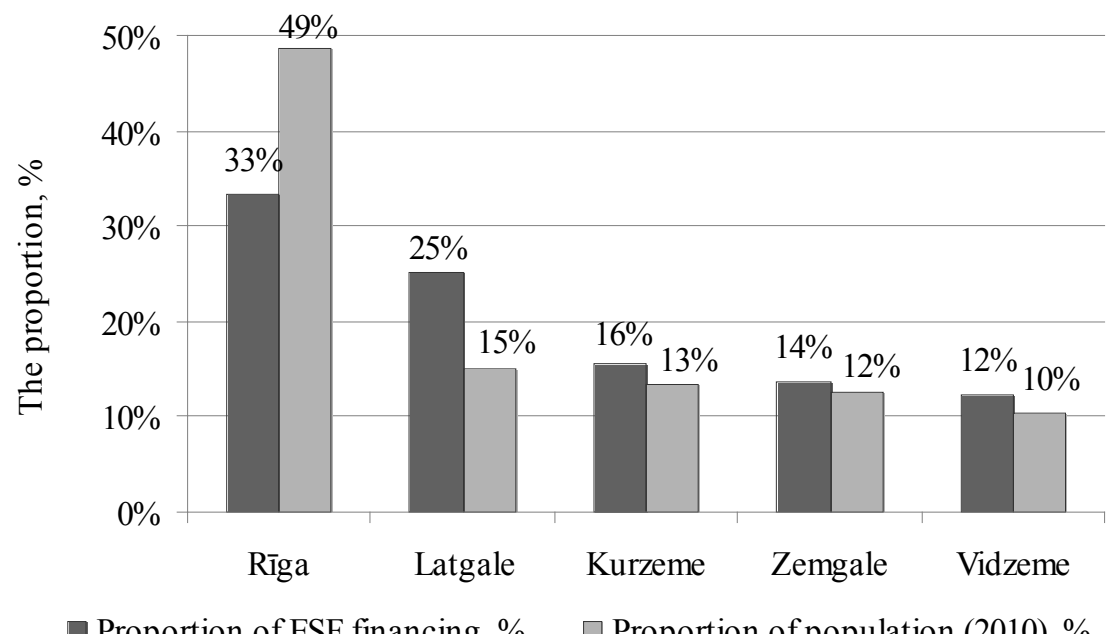

Source: data of the Ministry of Financing (Finanšu ..., 2011a), the Ministry of Welfare (Labklājīibas ..., 2011), and Central Statistical Bureau of Latvia (CSB, 2011a).

Fig. 2. Proportion of the acquired ESF financing and the number of population in the regions of Latvia, $\%$.

- also the highest indicator of the amount of the ESF financing in the welfare sector per one economically active inhabitant has been in Latgale, which was 2.6 times higher than in Riga region and exceeded the average indicator in the country 1.7 times. In the other three regions, the indicators differ among themselves from five to thirteen lats;

- indicators of the ESF financing in the welfare sector per one unemployed person indicate that the amount of financing in all regions has been very similar - the highest indicator was in Vidzeme (LVL 1357), but the lowest - in Riga region (LVL 1165). The obtained information allows concluding that the number of the unemployed in the regions has been taken into consideration in the allocation and acquisition of the ESF financing in the welfare sector and thus the equality principle has been observed and the execution of the overall goal of the EU funds to preclude regional and social inequality - has been facilitated;

- comparison of the ESF financing per one economically active businessperson shows that the values of the obtained indicators significantly differ from the previous considered cases. The highest indicator has been in Latgale, where it was seven times larger than in Riga region and 3.4 times exceeded the average indicator in the country. The research suggests that the large differences in the indicators could be explained by the differences in the number of economically active businesspersons in the regions, because, according to the information published by the $\mathrm{CSB}$, the number of businesspersons in Riga region, calculating the average number from 2004 till 2010, 9.4 times exceeded the indicator in Latgale. In the other three regions, the indicators have been very similar, but it should be concluded that, taking into consideration the distribution of the number of businesspersons in the regions (except Riga region), these indicators have been almost twice lower than in Latgale;

- the summarised and analysed information allows concluding that in this case one fourth of the ESF financing in the welfare sector has been received in Latgale, whose socio-economic indicators were the lowest in the country, and thus it has contributed to the execution of the overall goal of the EU funds - to preclude regional and social inequality.

In addition to the performed analysis, the invested ESF financing in the welfare sector from 2004 till 2010 has also been analysed in the context with such socio-economic indicators as proportion of population in the regions in 2010 and the territory development index in the regions in 2010.

Comparing the indicators of the acquired ESF financing in the welfare sector with the distribution of the number of population in the regions of Latvia (Fig. 2), it can be concluded that in the proportion of the distribution of the ESF financing in the welfare sector in the regions the ESF financing is close to the distribution of the proportion of the number 
of population. The largest differences have been observed in Latgale and Riga region. Indicators in Riga region indicate to a positive tendency the allocation of the ESF financing in the welfare sector was reallocated from Riga region for the benefit of all the other regions, especially Latgale, where there was almost twice as much financing than in case the financing was allocated according to the number of population. In Kurzeme, Vidzeme and Zemgale, considering the distribution of the proportion against the number of population, the contribution of the ESF financing allocation was between $2 \%$ and $3 \%$.

The information summarised in Figure 3 about the indicators of the attracted ESF financing in the welfare sector in the regions and the territory development indices allows observing that the largest ESF financing in the welfare sector per capita has been in the regions with a lower territory development index. Whereas, the largest total amount of the ESF financing in the welfare sector has been attracted in Riga region, whose territory development index was the highest, but among the other four regions, the largest amount of the total attracted ESF financing in the welfare sector has been the highest in Latgale where the territory development index was the lowest of all the regions.

\section{Impact of the ESF financing in the welfare sector on the changes in the socio-economic indicators of the regions of Latvia}

To evaluate the potential impact of the ESF financing in the welfare sector, the correlation analysis was performed to clarify the closeness of correlations among the socio-economic indicators of regions and the attracted ESF financing in the welfare sector (Table 2).

Because during the research several socioeconomic indicators by regions were available only until 2009 in the database of the CSB, the analysis comprises the period from 2004 till 2009.

To reveal the differentiated indicators, to model relationships and to determine the closeness of correlations, the averages of the researched indicators in the regions were calculated, and they were used for calculating Pearson coefficient in further research. The sample is small, thus the type and characteristics of correlations correspond to normal distribution. Evaluating the values of the obtained correlation coefficient ( $\mathrm{r}$ ), the corresponding closeness of the correlation was determined. The deviation $-\mathrm{p}=0.05$ and $\mathrm{r}_{\text {crit }}=0.811$.
Analysis of the information presented in Table 2 reveals large differences in the closeness of correlations, and evaluating the summarised information the author concludes that:

- in all regions and in Latvia in total, a particular impact of the ESF financing in the welfare sector on the changes in the number of the unemployed and job seekers is observed. The author justifies the increase in the number of the unemployed and in the number of job seekers by the ESF support requirement that only those persons may participate in the ESF financed measures who have been registered as the unemployed and job seekers within the SEA. Thus, the inactive inhabitants who had not registered within the SEA as the unemployed (since they were not candidates for the unemployed status because they had worked illegally and no social security taxes were paid for them), or those who considered that they would be able to find jobs themselves have become active and have obtained the status of the unemployed or the job seeker to participate in the ESF financed measures. This indicates to the impact of the ESF financing on the changes of the indicators, in this case - on the increase in the number of the unemployed in the regions and in Latvia in total. The fact that the reduction in workplaces in 2008 and 2009 caused by the economic downturn in Latvia, which in its turn was caused by the world financial crisis, has had a certain impact on the changes in the indicators also should be mentioned;

- in all regions, except Kurzeme, the impact of the ESF financing in the welfare sector on the changes in the territory development index is observed. It can be concluded that a positive tendency is the fact that the negative evaluation of the territory development index in Vidzeme, Latgale and Zemgale has reduced by $0.09,0.175$ and 0.025 units respectively. In Riga region the positive evaluation of the index has reduced by 0.04 units, but in Kurzeme the evaluation of the negative index has increased by 0.273 units; however, it has to be taken into consideration that the value of the territory development index of these regions could have been even lower without the ESF financing.

To compare the closeness of the comparable correlations, determination coefficients $\mathrm{R}^{2}$ that characterise the impact of the ESF financing in the welfare sector on the selected socio-economic indicators were calculated. Performing calculations, 


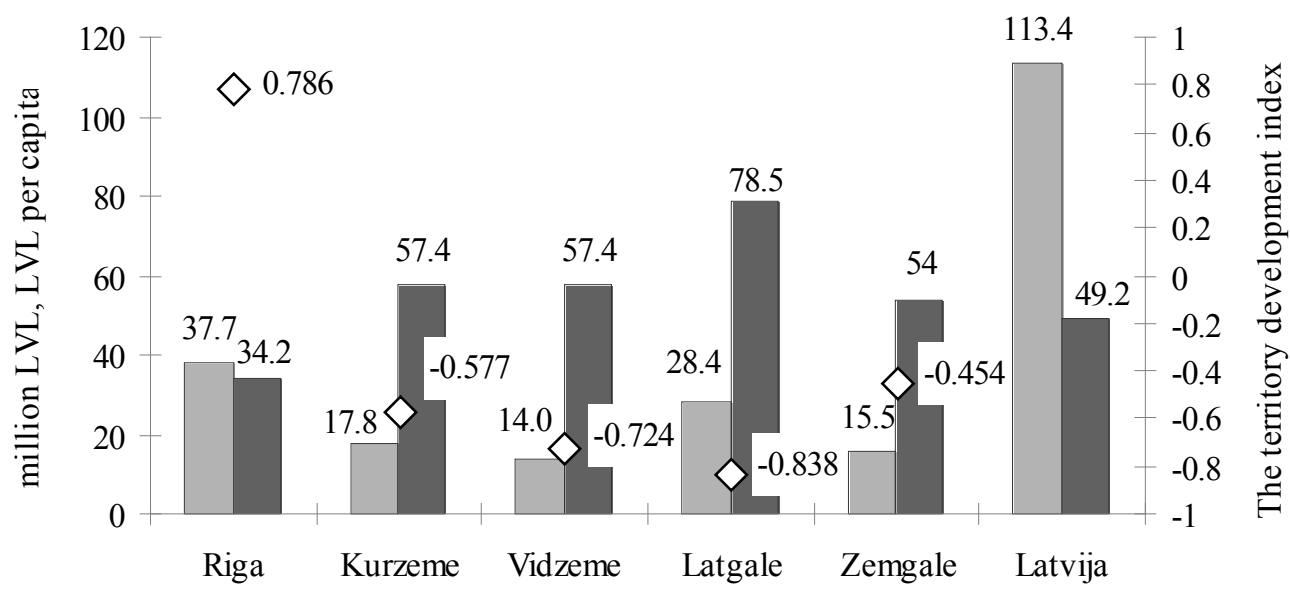

$\square$ ESF financing, million LVL

ESF financing per capita, LVL

$\diamond$ The territory development index (2010)

Source: data of the Ministry of Financing (Finanšu ..., 2011a), the Ministry of Welfare (Labklājības ..., 2011), and Central Statistical Bureau of Latvia (CSB, 2011a).

Fig. 3. Distribution of the acquired ESF financing in the welfare sector in the regions, million LVL, and the territory development index in 2010, LVL per capita.

Table 2

Correlation coefficients of the ESF financing in the welfare sector and socio-economic indicators in the regions of Latvia (averages in the period from 2004 to 2009)

\begin{tabular}{|c|c|c|c|c|c|c|}
\hline Indicators & Riga & Kurzeme & Vidzeme & Latgale & Zemgale & Latvia \\
\hline Economically active inhabitants & 0.167 & -0.096 & 0.349 & 0.266 & 0.257 & 0.236 \\
\hline Job seekers & 0.294 & 0.501 & 0.657 & 0.749 & 0.530 & 0.524 \\
\hline Economically inactive inhabitants & -0.434 & 0.074 & -0.581 & -0.152 & -0.461 & -0.335 \\
\hline $\begin{array}{l}\text { Number of registered unemployed } \\
\text { persons }\end{array}$ & 0.837 & 0.824 & 0.877 & 0.755 & 0.861 & 0.863 \\
\hline Number of the employed & -0.225 & -0.444 & -0.642 & -0.144 & -0.304 & -0.365 \\
\hline GDP in actual prices & 0.355 & -0.056 & 0.010 & -0.071 & 0.077 & 0.195 \\
\hline GDP per capita & 0.365 & -0.058 & 0.001 & -0.082 & 0.071 & 0.223 \\
\hline Jinni coefficient & 0.220 & -0.483 & -0.347 & -0.251 & 0.918 & -0.181 \\
\hline Poverty risk index & 0.225 & -0.268 & -0.476 & -0.230 & 0.828 & -0.044 \\
\hline Territory development index & -0.878 & -0.299 & 0.878 & 0.906 & 0.598 & - \\
\hline $\begin{array}{l}\text { Average gross monthly salary of } \\
\text { the employed }\end{array}$ & 0.505 & 0.446 & 0.415 & 0.414 & 0.404 & 0.466 \\
\hline $\begin{array}{l}\text { Average net monthly salary of the } \\
\text { employed }\end{array}$ & 0.478 & 0.428 & 0.401 & 0.396 & 0.387 & 0.441 \\
\hline $\begin{array}{l}\text { Household income, average per } \\
\text { one household member per month }\end{array}$ & 0.366 & 0.207 & 0.323 & 0.235 & 0.225 & 0.260 \\
\hline Total value added in the regions & 0.326 & -0.084 & -0.010 & -0.087 & 0.061 & 0.111 \\
\hline $\begin{array}{l}\text { Number of economically active } \\
\text { businesspersons per } 1000 \\
\text { inhabitants }\end{array}$ & 0.509 & 0.355 & 0.408 & 0.381 & 0.313 & 0.437 \\
\hline
\end{tabular}




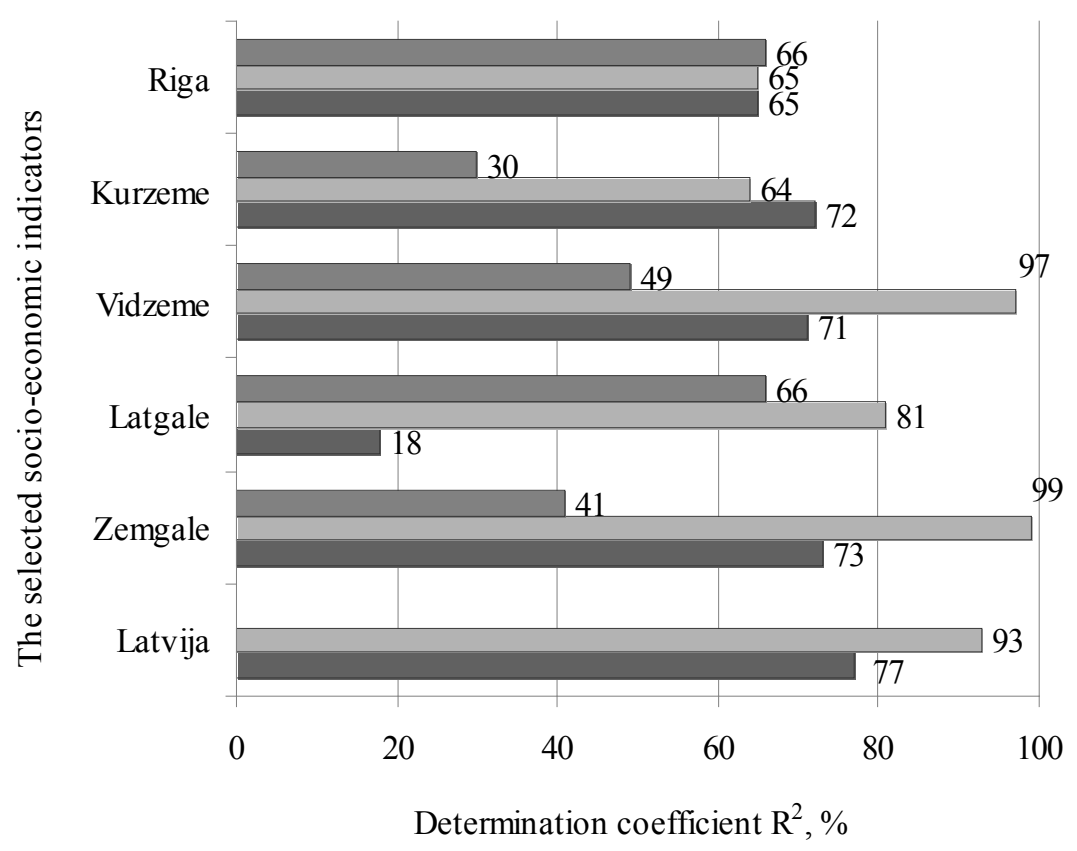

The number of registered as unemployed $\square$ The number of job seekers $\square$ The territory development index

Fig. 4. Determination coefficients of the acquired ESF financing in the welfare sector in Latvia and its regions, and the socio-economic indicators.

those correlations whose coefficients reveal weak closeness of the correlation $(|\mathbf{r}|<0.5)$ were excluded, and determination coefficients were calculated for those obtained values among which there exists statistically significant and close correlation.

In Latvia and all its regions (Fig. 4), functional correlations can be observed between the ESF financing in the welfare sector and the changes in the socio-economic indicators. When the ESF financing increases, the number of registered unemployed persons and job seekers increases proportionally, as well as changes in the territory development indices of the regions are observed, which allows concluding that the ESF financing in the welfare sector influences the development of socio-economic processes. The information summarised in Figure 4 reveals the following averages in the 2004-2009 period:

- $\quad$ increase in the number of registered unemployed persons in correlation with the ESF financing in the welfare sector explains the average increase within the given period in Latvia in the amount of $77 \%$, in Zemgale - $73 \%$, in Kurzeme $72 \%$, in Vidzeme $-71 \%$, and in Riga $-65 \%$. The lowest indicator was observed in Latgale, where the variation of the ESF financing in the welfare sector explains the average increase in the number of the unemployed in that period in the amount of $18 \% ; 82 \%$ is explained by other unlisted factors;

- $\quad$ increase in the number of job seekers in Latvia and all the regions, except Riga, in correlation with the ESF financing in the welfare sector explains the average increase within the given period in the amount of $99 \%$ in Zemgale, $64 \%$ in Kurzeme, $97 \%$ in Vidzeme, and $81 \%$ in Latgale; - value increase of the territory development index in correlation with the ESF financing in the welfare sector explains the average increase within the given period in Latgale and in Riga in the amount of $66 \%$, in Vidzeme - $49 \%$, and in Zemgale $-41 \%$. The lowest indicator was observed in Kurzeme, where the variation of the ESF financing in the welfare sector explains the average increase in the territory development index in that period in the amount of $30 \% ; 70 \%$ is explained by other unlisted factors.

\section{Conclusions}

1. In the period from 2004 till 2010, the total available and acquired ESF financing in the welfare sector was LVL 113.4 mill., of which the largest amount of the ESF financing (33\%) 
was attracted in Riga region, the second largest - in Latgale, where $25 \%$ of the ESF financing of the total acquired ESF financing was invested in the development of the region. In Kurzeme, Zemgale and Vidzeme regions, the proportion of the invested ESF financing differed by two to four percent points, which indicates equal distribution of financing among these three regions.

2. Comparing the attracted and acquired ESF financing in the welfare sector from 2004 till 2010, it has to be concluded that the contribution of the ESF financing in the welfare sector reveals a positive tendency - one fourth of the ESF financing in the welfare sector has been received by Latgale whose socio-economic indicators are the lowest in the country, and thus it has contributed to ensuring the execution of the overall goal of the EU funds - to preclude regional and social inequality.

3. The distribution of the proportion of the ESF financing in the welfare sector is close to the distribution of the proportion of the number of population in the regions. The largest differences can be observed in Latgale and in Riga region, which indicates to a positive tendency that allocation of the ESF financing in the welfare sector has been reallocated from Riga region for the benefit of all the other regions, especially Latgale, which has received almost twice as much as in case the financing was allocated according to the number of population. Comparing with the distribution of the proportion of the number of population, the contribution of the allocation of the ESF financing in the welfare sector was between $3 \%$ and $2 \%$.

4. The ESF financing in the welfare sector per capita has been received in regions with a lower territory development index. However, the largest total amount of the ESF financing in the welfare sector was attracted in Riga region whose territory development index was the highest, but among the other four regions, the largest amount of the total ESF financing in the welfare sector was in Latgale whose territory development index was the lowest among all the regions.

5. The ESF financing in the welfare sector has influenced the socio-economic indicators of the regions. Functional correlations were observed between the ESF financing in the welfare sector and the changes in the number of registered unemployed persons, the number of job seekers and the territory development index. When the ESF financing increased, the number of registered unemployed persons and job seekers also increased proportionally, as well as the increase in the territory development index in Zemgale, Vidzeme and Latgale was observed.

\section{References}

1. Bikse, V. (2009). Latvijas progress uzñēmējdarbības izglītības attīstībā pēc iestājas Eiropas Savienībā. Rīga: Eiropas Komisijas pārstāvniecība Latvijā.

2. Blumberga, S. (2010). Eiropas Savienības fondu efektivitāte Latvijā. Scientific Journal of Riga Technical University. Economics and Business. Economy: Theory and Practice, 20, 33-40.

3. Clinch, P., Convery, F., \& Walsh, B. (2002). After the Celtic Tiger. Challenges Ahead. Dublin: The O'Brien press.

4. CSB. (2011a). Iedzīvotāji un sociālie procesi. Retrieved from http://www.csb.gov.lv/csp/ content/ ?cat $=2220$

5. CSB. (2011b). Statistikas uzn̄èmumu registrs. [Data file]. Retrieved from http://data.csb.gov. lv/DATABASE/uzreg/databasetree.asp?lang=16

6. Dubra, E. (2006). Latvijas strukturālās, sociālās un darba tirgus politikas pilnveidošanas aspekti. Konkurence, integrācija, kooperācija: Baltijas reǵiona ekonomikas attīstības reǵionālie un starptautiskie aspekti (pp. 9-16). Rīga: Baltijas Forums.

7. Dubra, E. (2009). Latvijas ekonomikas konkurētspēja un investīciju nozìme tās veicināšanāa: monogrāfija. Rīga: LU Akadēmiskais apgāds.

8. Finanšu ministrija. (2007). Valsts stratēgiskais ietvardokuments 2007.-2013. gada periodam. Retrieved from http://www.esfondi.lv/ page. php?id $=478$

9. Finanšu ministrija. (2011a). ES fondu ieviešana. Retrieved from http://www.esfondi.lv/page. php?id=1112.

10. Finanšu ministrija. (2011b). ES fondu uzraudzība. Retrieved from http://www.esfondi. lv/page.php?id=920.

11. Haite, I. (2010). Sustainable development planning experience in Rēzekne. In Economic Science for Rural Development: Proceedings of the International Scientific Conference, No. 23 (pp. 26-30). Jelgava: LLU. 
12. Keišs, S., Tilta, E., Zariṇa, V., Jesemčika, A., Medne, A., Kazinovskis, A., \& Balode, G. (2008). Reǵionalizācija un tās loma līdzsvarotā administratīvi teritoriālā attīstībā Latvijā. $L Z P$ Ekonomikas, juridiskās un vēstures zinātnes galvenie pētījumu virzieni 2008. gadā, 14, 85-92.

13. Labklājības ministrija. (2011). SF aktivitāšu uzraudzība. Retrieved from http://sf.lm.gov.lv/ lv/par-fondiem/es_aktivitasu_uzraudziba/

14. Marciniak, M. (2009). Absorbtion of structural funds in the context of information society development on rural areas. In Economic Science for Rural Development: Proceedings of the International Scientific Conference, No. 18 (pp. 210-216). Jelgava: LLU.

15. Meyers, W.H., Kazlauskiene, N., Naujokiene, R., \& Kriščiukaitiene, I. (2006). Lessons learned and challenges in rural development programmes of Lithuania. In Žemes ūkio mokslai: Proceedings of the International Scientific Conference, T. 10 (pp. 10-18). Vilnius: Lietuvas Mokslu akademijus leidekla.

16. Mickievicz, P. (2007). Investment by agricultural holdings under programmes co-funded by the EU. In Economic Science for Rural Development: Proceedings of the International Scientific Confernce, No. 14 (pp. 122-129). Jelgava: LLU.

17. Mickiewicz, A., \& Mickiewicz, B. (2010). Polish food sector in the European Union. In Economic Science for Rural Development: Proceedings of the International Scientific Conference, No. 21 (pp. 45-52). Jelgava: LLU.

18. Mizik, T. (2007). Rural development in Hungary after the accession - the Role of EU co-financed programs. In Managing Economic, Social and Biological Transformation: Proceedings of the First Green Week Conference (pp. 108-115). Germany: Margraf Publishers GmbH.

19. Pilvere, I. (2007). EU agriculture structural fund support results in Latvia. In Žemes ūkio mokslai: Proceedings of the Interantional Scientific Conference, T. 14 (pp. 145-150). Vilnius: Lietuvas Mokslu akademijus leidekla.

20. PKC SIA. (2005). ES struktūrfondi un teritoriju attīstība Latvijā. Projekts "Atbalsts ES struktūrfondu ieviešanai: komunikācijas stiprināšana”. Rīga: "PKC” SIA.

21. Ribašauskiene, E., Kairyte, E., \& Meyers, W.H. (2007). Territorial dimensions of Lithuanian rural development plan 2004-2006: Lessons for 2007-2013. In Žemes ūkio mokslai: Proceedings of the International Scientific Conference, T. 14 (pp. 11-18). Vilnius: Lietuvas Mokslu akademijus leidekla.

22. Saktiņa, D. (2008). Sociāli ekonomiskās attīstības izvērtējums klasifikācijā noteiktajos atšķirīgo lauku tipu reǵionos, ES atbalsta pasākumu ietekmes izvērtējums, klasifikācijas pilnveidošana lauku politikas īstenošanas vajadzībām. LZP Ekonomikas, juridiskās un vēstures zinātnes galvenie pētījumu virzieni 2008. gadā, 14, 125-126.

23. Saktina, D., \& Meyers, W.H. (2005). Eiropas Savienības līdzfinansētās un nacionālās lauku atbalsta programmas Latvijā: gatavojoties jaunajam programmēšanas periodam. Rīga: LVAEI.

24. Sienkiewicz, J. (2009). Use of the EU public funds in agriculture on the example of the Western Pomeranian regions. In Economic Science for Rural Development: Proceedings of the International Scientific Conference, No. 18 (pp. 99-104). Jelgava: LLU.

25. Slavinska, I. (2005). Kvalitatīvas dzīves vides izveide - viens no Latvijas lauku attīstības virzieniem. Rural Development in the Expanded Europe at the Beginning of the 21st Century, 8, 124-130.

26. Sweeney, P. (2008). Ireland's Economic Success, Reasons and Lessons. Dublin: New Island.

27. Tetere, V. (2009). European structural funds - part of investment in Latvia's development. In Economic Science for Rural Development: Proceeding of the International scientific conference, No. 18 (pp. 240-245). Jelgava: LLU.

28. Tetere, V., \& Pilvere, I. (2007). EU structural funds for rural development of Latvia's economy. In The Economics and Social Issues of Sustainable development: Proceedings of the International scientific conference, Vol. III (pp. 109-117). Szczecin: Agricultural University in Szczecin.

29. Vaidere, I. (2006). Regionālā politika un pašvaldību attīstība Eiropas Savienībā un Latvijā. Rīga: LU Akadēmiskais apgāds, Latvijas statistikas institūts.

30. Vītola, A., \& Šenfelde, M. (2010). Reǵionālo finansējuma kvotu piemērošanas iespējas ilgtspējīgas reǵionālās attīstības veicināšanai. Rīgas Tehniskās universitātes zinātniskie raksti, 14. sērija (Ilgtspējīga telpiskā attīstība), 1. sējums, 58-61. 
31. Zawojska, A. (2009). Impact assessment of the European Union funds to support rural population and economy in Poland. In Economic Science for Rural Development: Proceedings of the International Scientific Conference, No. 18 (pp. 150-156). Jelgava: LLU.
32. Zvirgzdin̦a, R. (2007). Uzṇēmējdarbība un tās attīstības iespējas Latvijas reǵionos. In Economic Science for Rural Development: Proceedings of the International Scientific Conference, No. 10, (pp. 54-61). Jelgava: LLU.

\section{Acknowledgements}

The academic study and the publication were financed by the project "Support for Doctoral Studies at Latvia University of Agriculture" /2011/0055/1DP/1.1.2.1.2/ 11/IPIA/VIAA/008/, Agreement No. 04.4-08/EF10. PD.02. 